C

yfrowa szkoła - czyli jaka?" - pod takim tytułem przygotowano cykl konferencji regionalnych przeznaczonych dla bibliotekarzy bibliotek szkolnych i pedagogicznych oraz nauczycieli. Głównymi organizatorami tych imprez były: Magazyn „EduFakty - Uczę Nowocześnie”, Sekcja Bibliotek Pedagogicznych i Szkolnych Stowarzyszenia Bibliotekarzy Polskich, serwis Elektroniczna Biblioteka Pedagogiczna oraz pięć bibliotek pedagogicznych, w których spotkania te miały miejsce. Pierwsza konferencja z cyklu odbyła się 14 listopada 2012 r. w Bibliotece Pedagogicznej im. gen. bryg. prof. Elżbiety Zawackiej w Toruniu.

Po przywitaniu gości i sponsorów dyrektor biblioteki Elżbieta Wykrzykowska przedstawiła główny cel spotkania, a więc próbę odpowiedzi na pytanie, czym jest cyfrowa szkoła i jakie niesie konsekwencje dla pracy nauczycieli - także nauczycieli-bibliotekarzy. Następnie głos zabrał pierwszy prelegent, Janusz S. Wierzbicki. Zwrócił on uwagę, że już dzisiaj wiele szkół realizuje ideę „cyfrowej szkoły”. Jako przykłady podał m.in. Gimnazjum w Nowym Tomyślu, które zakupiło tablety przeznaczone dla uczniów i nauczycieli, projekt Marka Sobczaka nauczyciela z Jarocina, który podczas lekcji wychowania fizycznego zaproponował uczniom stworzenie za pomocą laptopów prezentacji poszczególnych ćwiczeń, czy przygotowany przez Ka-

\section{"Cyfrowa szkoła - czyli jaka?" Konferencja z okazji obchodów 90-lecia Biblioteki Pedagogicznej im. gen. bryg. prof. E. Zawackiej w Toruniu (Toruń, 14 listopada 2012 r.)}

DOI: $10.12775 /$ TSB.2013.018

tarzynę Wilk kurs języka niemieckiego dla gimnazjalistów z Panek. Jak przekonywał prelegent, podobnych inicjatyw jest dużo więcej. Cyfrowa szkoła nie jest więc czymś z odległej przyszłości, lecz staje się rzeczywistością już dziś.

Referent spróbował także odpowiedzieć na pytanie, jakie są zadania cyfrowej szkoły. Jego zdaniem, cyfrowa szkoła przede wszystkim uczy, wychowuje i przygotowuje do życia - tak jak „normalna” szkoła. Ponadto wyposaża ucznia w odpowiednie kompetencje, nie tyle związane $\mathrm{z}$ posługiwaniem się konkretnymi narzędziami (bo te zmieniają się bardzo szybko), ile z podejściem do technologii informacyjno-komunikacyjnych obecnych w różnych aspektach życia. „Nowa szkoła" przygotowuje również do samokształcenia i dokształcania się. $\mathrm{Z}$ tego powodu niezwykle ważne wydaje się odpowiednie wyposażenie szkół. Niestety, nie gwarantuje to pełnego sukcesu. Uczeń na co dzień przebywa w cyfrowym środowisku - już 
około $90 \%$ gospodarstw domowych w Polsce ma dostęp do Internetu, więc sieć jest dla młodych ludzi ich naturalnym środowiskiem, którego oczekują także w szkole. Szkoła musi więc dostosować język, narzędzia i usługi do potrzeb dzieci i młodzieży, zachowując jednocześnie pewien kanon działań, w czym także niemałe znaczenie mają biblioteki szkolne. Cyfrowa szkoła musi sprostać oczekiwaniom uczniów, ale i odpowiadać na potrzeby nauczycieli, rodziców i administracji.

Kolejny problem, na który zwrócił uwagę J. S. Wierzbicki, to planowanie stworzenia cyfrowej szkoły. Tego procesu nie powinno się rozpoczynać od zakupu sprzętu, lecz od identyfikacji potrzeb ucznia, nauczyciela, rodzica, administracji. Należy zwrócić uwagę na to, co już szkoła posiada, czego jej brakuje, co mogą zaoferować sami uczniowie czy nauczyciele. Planowane zmiany powinny gwarantować zgodność (spójność), funkcjonalność, komplementarność sprzętu i być dostosowane do możliwości placówki.

Swój wykład J. S. Wierzbicki zakończył prezentacją różnych urządzeń (m.in. tablet, komórka, miniprojektor) i ich zastosowania w procesie edukacji. Następnie uczestnicy konferencji mieli okazję zobaczyć, jak funkcjonuje jeden z produktów oferowany przez Young Digital Planet. W ramach zainicjowanej telekonferencji Jolanta Gałecka przedstawicielka firmy - opowiedziała o możliwościach zastosowania m.in. gier edukacyjnych w procesie kształcenia.

Kolejne wystąpienie autorstwa J. S. Wierzbickiego oraz Bartosza Krzyżaniaka dotyczyło redagowania informacji na potrzeby Internetu lub czasopisma. Prelegenci rozpoczęli od przedstawienia różnych typów informacji występujących na stronach internetowych oraz w czasopismach, a także różnic między nimi. Następnie omówili zasady redagowania przykuwającego uwagę artykułu, jego elementy - zarówno obowiązkowe, jak i opcjonalne. Na koniec wzbogacili swoją prezentację przykładami źle zredagowanych tekstów. Zwrócili uwagę na różne typy błędów: od interpunkcyjnych, przez pomyłki w nazwach własnych, po źle skonstruowane zdania.

Ostatnia część konferencji nosząca tytuł „Za i przed kamerą - jak filmować, zadawać pytania i występować?" została przygotowana przez Macieja Kułaka i J. S .Wierzbickiego. Podczas wykładu połączonego z prezentacją zostały omówione różne problemy związane z pracą przed kamerą. Zwrócono uwagę m.in. na to, jak właściwie przygotowywać reportaż czy wywiad, w jaki sposób należy operować obrazem, by był on atrakcyjny dla odbiorcy, a także na znaczenie dźwięku podczas nagrania i niektóre kłopoty z nim związane. Dodatkowo autorzy wystąpienia podali kilka wskazówek dotyczących 
tego, jak samemu występować przed kamerą i unikać typowych błędów (np. niewłaściwego ubioru czy zachowania). Zaznaczono, że nie trzeba mieć profesjonalnego sprzętu, by móc stworzyć film - dziś do tego może służyć nawet telefon komórkowy.

Zarówno druga, jak i trzecia część konferencji były rodzajem wprowadzenia do warsztatów, które odbyły się dzień później (15 listopada). Nauczyciele i bibliotekarze mogli w praktyce zastosować wszelkie wskazówki podane podczas wykładów. Zajęli się m.in. poprawnym redagowaniem tekstów (skracano je, nadawano im tytuły i lidy, poprawiano błędy językowe). Ich zadaniem było także przygotowanie nagrań własnych wypowiedzi.

Konferencja cieszyła się sporym zainteresowaniem. Wskazówki przedstawione przez prelegentów z pewnością przydadzą się w codziennej pracy bibliotekarza szkolnego, który jest współodpowiedzialny za realizację właściwej edukacji medialnej w szkole. Uczestnicy konferencji mieli okazję zapoznać się z różnymi nowinkami technicznymi, które wzbogacają proces nauczania, a jednocześnie przekonać się, że nawet przy użyciu prostych środków proces kształcenia można uczynić bardziej atrakcyjnym i efektywnym.

Konferencją „Cyfrowa szkoła - czyli jaka?” toruńska biblioteka pedagogiczna rozpoczęła cykl konferencji. Podobne spotkania odbyły się także w bibliotekach pedagogicznych w Katowicach, Warszawie, Białymstoku i Łodzi. Tego typu imprezy z pewnością mogą stać się impulsem do wprowadzania nowych rozwiązań technologicznych w polskich szkołach. Są doskonałą formą podnoszenia kwalifikacji bibliotekarzy i poszerzania ich wiedzy. Warto, by podobne spotkania odbywały się częściej.

\section{Ewa J. Kurkowska}

Instytut Informacji Naukowej i Bibliologii Uniwersytetu Mikołaja Kopernika w Toruniu 